\title{
Plantaginaceae in the flora of Egypt 1.Systematic revision of the indigenous taxa
}

\author{
Amal Hosny \\ and \\ Nahed M. Waly \\ The Herbarium,Faculty of Science, \\ Cairo University, Giza-12613,Egypt.
}

Hosny, A. and Waly, N. M. 2001. Plantaginaceae in the flora of Egypt.1.Systematic revision of the indigenous taxa. Taeckholmia 21(2):239-255.

Plantago is the representative genus of Plantaginaceae in Egypt, it comprises 19 species of which Plantago weldenii Rchb. is recorded new to the flora of Egypt. Stem, leaf shape and size, and inflorescence are key characters while floral characters are useful for the separation between the closely allied taxa.

Key wards: Plantaginaceae, Plantago, systematic, Egypt.

\section{Introduction}

Plantaginaceae is a family of annual or perennial herbs. It comprises three genera and about 253 species widely distributed in temperate regions and mountains of the tropics. Plantago is the major genus with about 250 species, while Litorrella has two aquatic or shore species, and Bougweria is monotypic (Moore, 1978).

Plantago is readily distinguished by its usually rosulate foliage and apparent parallel venation, the spicate or capitate inflorescence on stout or wiry scapes, the 4merous flowers with membranous corollas, stamens much exerted on wiry filaments, bicarpellate gynoecium and a dehiscent capsule (pyxis) with two or more seeds.

Hallier (1912) and Wettstein (1935), included Plantaginaceae in Tubiflorae as allied to Scrophulariaceae. Bessey (1915), placed it in his Primulales as derived from or related to Plumbaginaceae. Hutchinson (1948), returned it to the Plantaginales and derived this order from primulaceous ancestors.

Plantaginaceae is represented in the flora of Egypt by the genus Plantago, which comprises 21 species and 7 varieties (Tackholm, 1974). El Hadidi \& Fayed (1994/1995) and Boulos (1995) reported the occurrence of 22 species.

The present account aims to revise critically the indigenous species of Plantago based on the collections kept in the Egyptian Herbaria in Particular (CAI \& CAIM), as well as field studies.

Phytogeographical subdivision for the representative specimens are those of El Hadidi ( 1993); Figure (1).

Received 20 February 2001. Revision accepted 5 November 2001. 


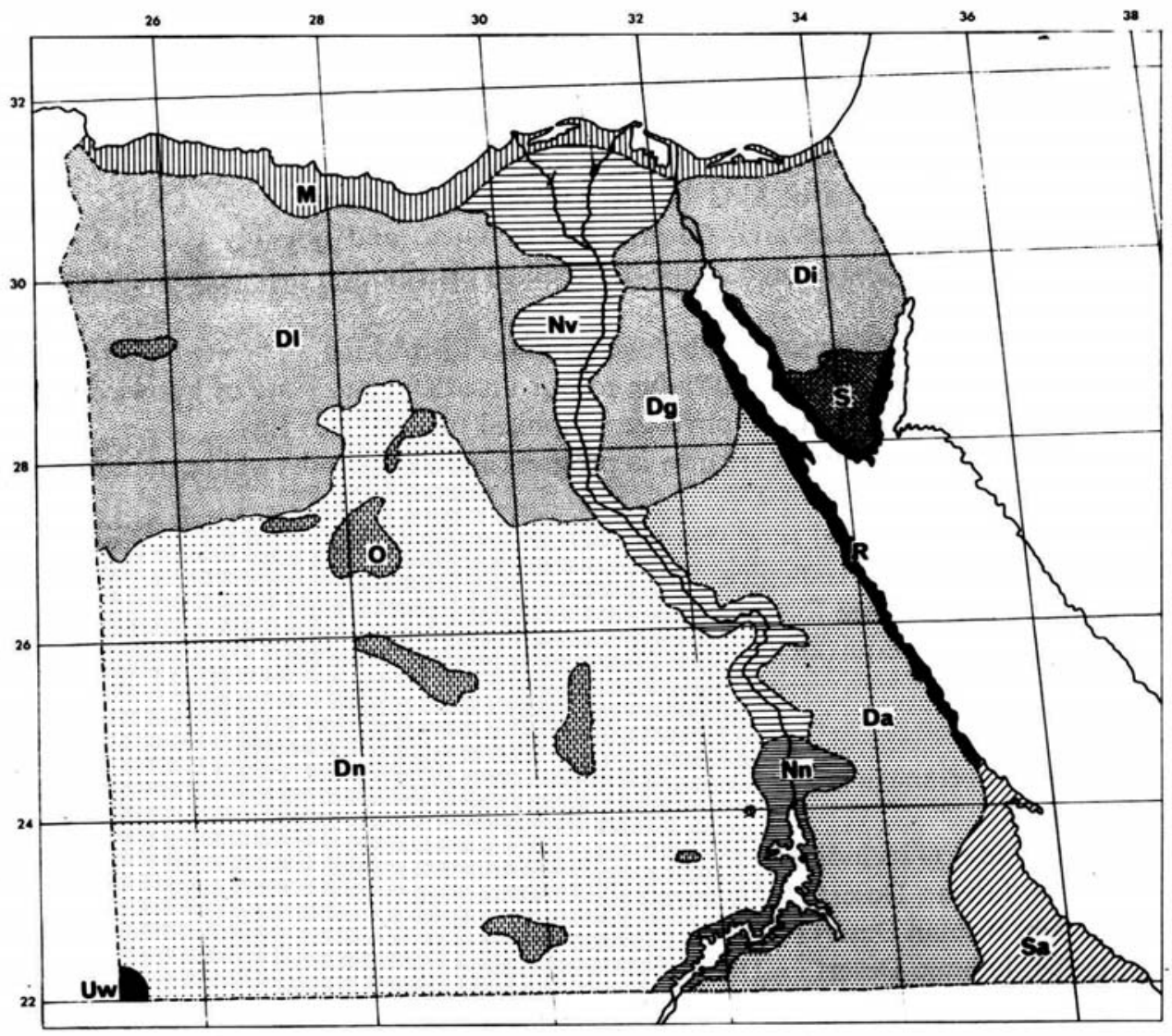

Figure 1. Phytogeographical subdivisions of Egypt. (M) Mediterranean coastal belt, (D1) Libyan Desert, (Dn) Nubian Desert, (Di) Isthmic Desert, (Dg) Galala Desert, (Da) Arabian Desert, (Nv) Nile Valley sector of the Nile-land, (Nn) Nile nubian sector of the Nile land, (O) Oases of (Dl) \& (Dn), (S) Southern mountainous Sinai, (R) Red Sea coastal plains, (Sa) Gebel Elba district; (Uw) Gebel Uweinat area.

\section{Systematic treatments}

\section{Characters of systematic value}

The present investigation revealed the presence of 19 species among which the following characters are of systematic value.

\section{a. The stem and leaves (Figure 2).}

Ten species which belong to subgenus Plantago are stemless or characterized by a very short basal stock on which leaves are crowded in rosettes. The other nine species are 
characterized by a distinct stem with mostly opposite leaves. Of these, six species belong to subgenus Psyllium with stems reaching $20 \mathrm{~cm}$ long; and three species which belong to subgenus Plantago viz. Plantago crassifolia, P. citiata and P.amplexicaulis which are characterized by a shorter stems not exceeding $5 \mathrm{~cm}$ long.

The leaf characters were found useful to distinguish between certain species, viz. Plantago major, P.lagopus and P. lanceolata which are characterized by large (5-20 x 1$16 \mathrm{~cm})$ and long or short petiolate leaves. Leaves are usually smaller $(4-15 \times 0.2-2 \mathrm{~cm})$ among the other recorded species and without a distinct petiole. They are usually entire or with a few teeth in Plantago ovata, P. cylindrica and P. albicans. Four species are characterized by leaves with prominent teeth or lobes viz. Plantago crypsoides, $P$. weldenii, $P$. notata and $P$. coronoupus.

\section{b. Inflorescence}

The inflorescence is usually distinguished into a lower cylindrical scape and an upper spike of varying shape and size. The length of scape varies between, twice the length of the leaves (10-30 cm long) in Plantago albicans, $P$. lanceolata, $P$. lagopus and $P$. crassifolia, or much shorter than leaves (not exceeding $6 \mathrm{~cm}$ long) in Plantago crypsoides and the species of subgenus Psyllium. The other species which belong to subgenus Plantago have subequal scape to its subtending leaves; its length mostly reaching $20 \mathrm{~cm}$ long (-35cm long in Plantago major).

The scapes in most of the species are terete, erect to ascending, procumbent and recurved in Plantago crypsoides and clavate in $P$. weldenii.

The spike varies in shape from the cylindrical (12 species) to ovoid or ovoidgloboid (7 species). In Plantago ovata and P.exigua, spikes are ovoid (c. $2 \times 1 \mathrm{~cm})$, with dense flowers in the former and lax flowers in the latter. Ovoid-globoid spike with mostly dense flowers is characteristic to Plantago amplexicaulis, $P$. squarrosa, $P$. arenaria and $P$. afra. The flowers are lax in the spike of $P$. sinaica. The cylindrical spike is long (10-15 cm long) in Plantago crassifolia and P. major, both with dense flowers, and in P. cylindrica and P. albicans with lax flowers. The other eight species have a shorter cylindrical spike (2-5 cm long) with dense flowers.

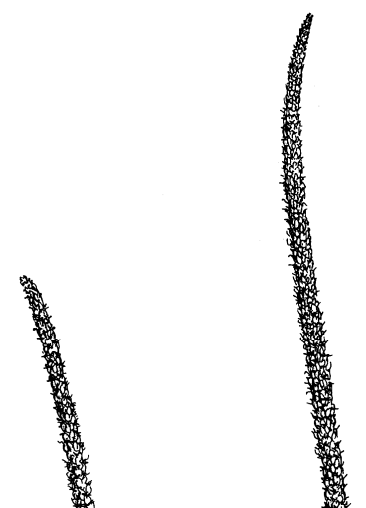






Figure 2.a. Plantago major, plant stemless, leaves ovate, petiolate, scape erect, spike elongate cylindrical, (x 0.5). b. P. crypsoides, leaves with lobed margin (x 0.75 ), scape procumbentcurved, spike short cylindrical.






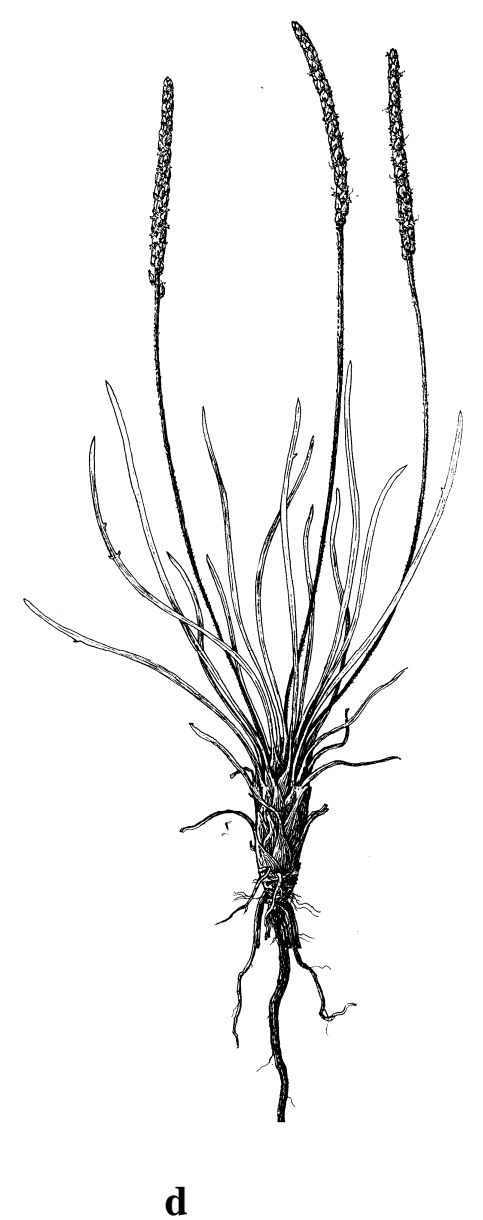

Figure 2, continued. c. $P$. arenaria, stem long, leaves sessile, entire, spike globoid, dense flowered. d. $P$. crassifolia, , stem short, leaves narrow linear (x 0.5).

\section{c. Floral bracts and sepals}

The floral bracts (Fig. 3) and sepals (Fig. 4) are reliable characters for the distinction of at least half of the investigated taxa. They are useful for the separation of pairs of habitually similar species. This is the case of the bracts and sepals which are hairy in Plantago ciliata, and are glabrous in the habitually similar P. amplexicaulis. The bracts are densely woolly and the sepals with apical woolly hairs in Plantago notata, these bracts are glabrous and the sepals with short marginal hairs in the habitually similar P.coronopus. Plantago exigua and P. afra are also habitually similar annual herbs with lax leaves on a cauline stem. Both species share some of the floral characters viz. colour of flower 
center, shape of posterior sepals and lower bracts; the latter are longer and larger than sepals in Plantago exigua and smaller and shorter than sepals in P. afra. Plantago squarrosa and $P$. arenaria are another two habitually similar species but can be separated by the size of the posterior sepals which are equal in the former and unequal in the latter.

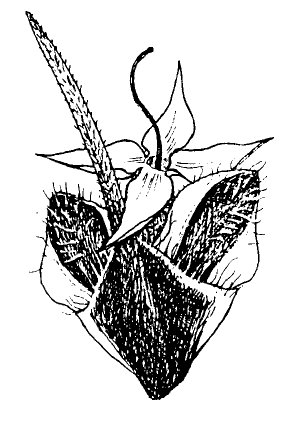

a

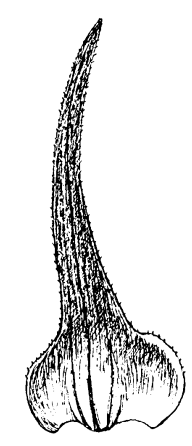

C

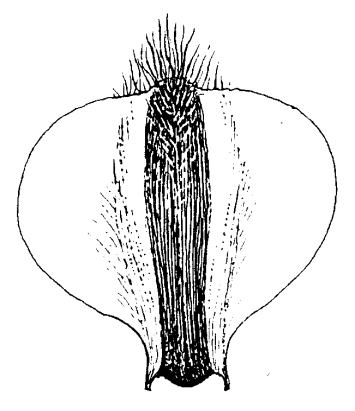

e

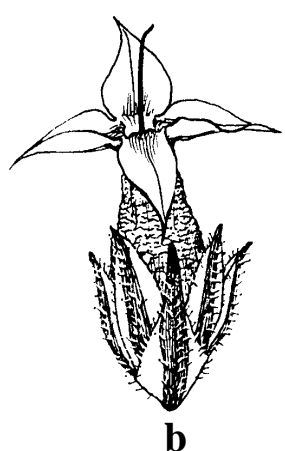

d

Figure 3. Lower bracts in, a. Plantago arenaria, (x 10) longer than sepals. b. P. afra, (x 5) shorter than sepals, c. $P$. squarrosa, (x 10) with broad clasping base and linear laminar part. d. $P$. exigua (x 3.5) ovate with narrow tip. e. P. cylindrica, (x 5) orbicular.

a
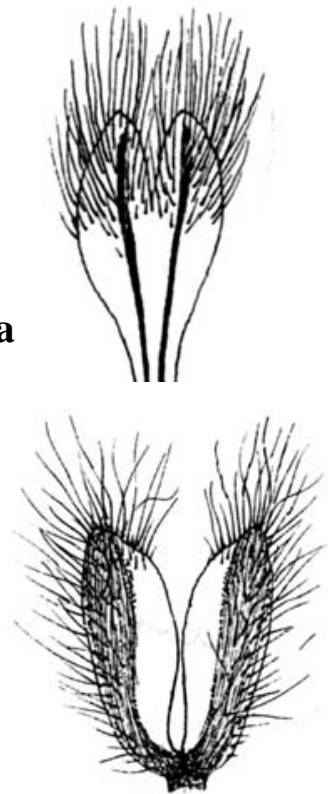
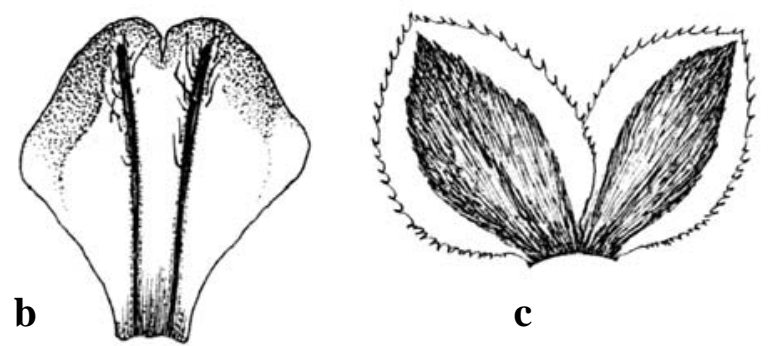
Figure 4. Anterior sepals in, a. Plantago lagopus, (x 7.5) united with long hairs. b. P. lanceolata, (x 7.5) united and glabrous. c. P. coronopus, (x 15) free, margin with short hairs. $P$. notata (x 7.5) free with apical woolly hairs. e. P. ciliata, (x 12) free, margin and apex with long hairs.

\section{Key to the species}

1.a. Plants with distinct stems, leaves mostly opposite .................................. 2

b. Plants stemless with rosettes of leaves ........................................ 10

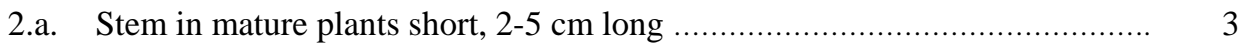

b. Stem in mature plants longer, more than $10 \mathrm{~cm}$ long ........................... 5

3.a. Perennial, leaves narrowly linear, 5-10 x 0.1-0.6 cm; scape 10-20 cm long, spike elongate cylindrical 5-12 cm long ........ $\quad$ 4. P. crassifolia

b. Annuals, leaves lanceolate to spathulate 3-18 x 0.5-1.5 cm; scape 2-15 cm long, spike short cylindrical up to $2.5 \mathrm{~cm}$ long or ovoid up to $3 \mathrm{~cm}$ long ...... 4

4.a. Leaves spathulate, $2-8 \times 1.5 \mathrm{~cm}$; bracts and sepals with long hairs on margin and apex; spike axis densely hairy

12. P. ciliata

b. Leaves lanceolate, $3-18 \times 0.5-1.5 \mathrm{~cm}$; bracts and sepals glabrous or rarely with a few hairs; spike axis glabrous ...

5.a. Perennial woody plant, leaves densely crowded on the stem $14 . P$ sinaica

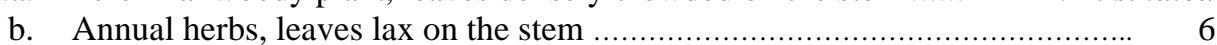

6.a. Flower center very dark, posterior sepals flat ................ 15. P. phaeostoma

b. Flower center pale, posterior sepals with a dorsal wing or ridge .............. 7

7.a. Lower bracts with broad clasping base and an ovate or linear laminar part ... 8

b. Lower bracts ovate to lanceolate with narrow tips ................................... 9

8.a. Leaves linear-spathulate 1-2.5 x 0.1-0.3 cm, posterior sepals equal

16. P. squarrosa

b. Leaves linear-lanceolate, 2-7 x 0.5-3.5 cm, posterior sepals unequal

17. P.arenaria

9.a. Lower bracts longer than sepals, $0.1-0.3 \mathrm{~cm}$ long ................... $\quad$ 18. P. exigua

b. Lower bracts shorter than sepals, $0.3-0.8 \mathrm{~cm}$ long ..................... 19. P. afra

10.a. Leaves ovate or broad lancolate, 1-4 (-16) cm broad .......................... 11

b. Leaves narrowly lanceolate - linear, $0.2-1.5 \mathrm{~cm}$ broad .......................... 13

11.a. Leaves ovate, 6-20 x 1-4(-16) cm, distinctly petiolate, anterior sepals free ............................................................. 1. Pajor

b. Leaves broad lanceolate, 5-15 x 1-2.5 cm, attenuated towards the base, anterior sepals united

12.a. Annual herb; anterior sepals with long hairs ...................... 8. P. lagopus 
b. Perennial herb or undershrub; anterior sepals glabrous or with few short hairs

7. P. lanceolata

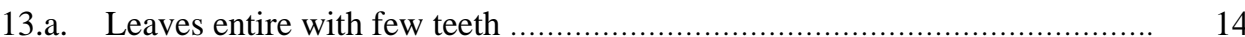

b. Leaves with prominent teeth or lobes .............................................. 16

14.a. Sepals glabrous, spike ovoid 11 P.ovata



15.a. Scape 1-9 cm long, equal or shorter than leaves, spike $1.5-13 \mathrm{~cm}$ long, flowers dense

10. P. cylindrica

b. Scape 7-30 cm long, twice the length of the leaves, spike 1-15 cm long, flowers lax ...................................... 9. P. albicans

16.a. Scape and spikes shorter than leaves, descending ............................... 17

b. Scapes and spikes longer than leaves, erect ........................................... 18

17.a. Scapes procumbent - recurved, sepals hairy ........................ 5. P.crypsoides

b. Scapes clavate, sepals glabrous .......................................... 3. P. wildenii

18.a. Bracts densely woolly, sepals with apical woolly hairs .............. 13. P. notata

b. Bracts glabrous or sparingly hairy, sepals with short marginal hairs

2. P. coronopus

\section{Synopsis of the Egyptian species of Plantago}

The taxa are arranged according to the system proposed by Pilger (1937).

\section{Subgenus: Plantago}

Section: Plantago

\section{P. major L}

Section: Coronopus

2. P. coronopus L.

* 3. P. weldenii Rchb.

4. P. crassifolia Forsskal

5. P. crypsoides Boiss.

Section: Bauphula

6. P. amplexicaulis Cav.

Section: Lagopus Gord.

7. P. lanceolata L.

8. P. lagopus L.

Section: Leucopsyllium Decne
9. P. albicans L.
10. P. cylindrica Forsskal
11. P. ovata Forsskal
12. P. ciliata Desf.
13. P. notata Lagasca

\section{Subgenus: Psyllium}

Section: Psyllium ( Juss)DC.

14. P. sinaica (Barneoud) Decne

15. P. phaeostoma Boiss. \& Heldr. 


\author{
16. P. squarrosa Murray \\ 17. $P$. arenaria waldst. \& Kit. \\ 18. P. exigua Murray \\ 19. P. afra L.
}

* New record to the flora of Egypt.

Note: Täckholm (1974), El Hadidi \& Fayed (1994/95) and Boulos (1995) reported the occurrence of Plantago sarcophylla (Boiss.)Zohary without certainty. The same authors reported the occurrence of Plantago chamaepsyllium Zohary and P.bellardi All.from Sinai Peninsula. No specimens belonging to the three species were seen or collected by the authors and their occurrence in Egypt is uncertain.

\title{
4. Enumeration of taxa
}

\section{Subgenus: Plantago L.}

=Euplantago Harms in Engler\& Plant., Pflanzenfam. IV,3b:370 (1895).

Annual or perennial herbs, generally stemless; leaves alternate usually rosulate.

\section{Section: Plantago L.}

=Polyneuron Decne, in DC.Prodr.13,1:694(1852).

Perennial, stemless herbs, leaves broad, distinctly petiolate ; seed minute angular.

\section{Plantago major L., Sp.Pl.ed.1:112(1753). (Fig. 1.a.)}

Type: In Europa ad vias, specimen no. 144/1 microfiche (LINN, holotype).

\section{Distribution}

Common weed in Farmland and moist places of Egypt. Known from temperate parts of the Old World; naturalized elsewhere.

\section{Representative specimens}

M: Sidi Gaber, 8.10.1907; Guvaine s.n. (CAI). Nv: Matoubas, Rosetta, 6.8.1971; Imam\&al. s.n. (CAI)-Mansoura, near the town, wheat field, 9.4.1971; Imam s.n. (CAI)- Cairo, Orman garden as a weed, 5.4.1928; Hassib s.n. (CAI)- El Fogai, Minia, 23.4.1941; Shabetai s.n. (CAI)- Kom ombo, 12.5.1959;M.Abdalla s.n. (CAIM)Asswan Dam area, 6.7.1967; El Hadidi \& Ghabbour s.n. (CAI). Di: Tel El-Kebir, 5.8.1931; Drar s.n. (CAIM). O: El Aguz, Bahariya oasis, 17.4.1935; Drar s.n. (CAI)Kharga Oasis, 2.8.1931; Drar s.n. (CAI).

Section: Coronopus DC., in Lam. \& DC., Fl.Fr. ed.3,3:417 (1805).

Annual or perennial, mostly stemless herbs; leaves narrow often pinnatly dentate; seed face with distinct hilum.

2. Plantago coronopus L., Sp.Pl.ed.1:115 (1753). (Fig.3.c.)

Type: In Europae glareosis, specimen no. 144/24 microfiche ( LINN, holotype).

\section{Distribution:}


Coastal plains and weed in barley field of the Mediterranean coastal lands of Egypt. Known from the Mediterranean region.

\section{Representative specimens}

M: Sidi Abdel Rahman, 8.3.1978; Imam \& Soliman s.n. (CAI)- Abu Mandour, 11.3.1978; Soliman s.n. (CAI).

*3. Plantago weldenii Rchb, Fl.Germ.Excurs. :396 (1831)

$=P$. coronopus L. subsp. weldenii (Rchb.) Arcag., Comp.Fl.Ital.:501 (1882)

$=P$. coronopus L. subsp. commutata (Guss.) Pilg. Fedd. Repert.Spec.Nov.Regni. 28:287 (1930).

= P. commutata Guss.; Suppl.Fl.Sicual.Prodr.1:46 (1832)

Type: In arenosis maritimis, Ustica Lampedusa, Italy; Gussone.

Note: The careful examination of the available materials of Plantago coronopus revealed the presence of two distinct taxa: $P$. weldenii with scape and spikes are descending and shorter than leaves; and $P$. coronopus with erect scape and spikes which are longer than leaves. Both species were regarded by some scholars as two subspecies of $P$. coronopus.

\section{Distribution}

Coastal plains along the Mediterranean sea and wadi beds of the Eastern desert in Egypt. Known from North Africa, eastwards to SW Asia and Arabian peninsula.

\section{Representative specimens}

M: Sidi Barrani, 19.4.1963; El Megid s.n. (CAI)- Saniet El-Hagg Aiyad, wadi Habs, between Mersa Matruh and Agiba, 23.3.1974; Tackholm \& al. s.n.(CAI)- Burg El Arab, 22.3.1956; El Hadidi s.n.(CAI)- El Arish, 20.3.1928; G.Tackholm s.n.(CAI). Di: Wadi El-Maghara, 22.4.1959; Boulos s.n.(CAI). Dg: Wadi Hof, 17.4.1922; Simpson 1114 (CAIM). Da: Wadi Araba, Red sea district, 9.2.1966; Tackholm \& Boulos s.n. (CAI)-Wadi Askhar, S. Galala, 11.3.1937; Shabetai 3612 (CAIM).

4. Plantago crassifolia Forssk., Fl.Aegypt.-Arab.:31 (1775). (Fig. 1.d.)

Type: Forsskal, no. 261 microfiche ( C, holotype).

\section{Distribution}

Confined in Egypt to the Mediterranean coastal planes, moist places and barely fields. Known from Eastern and southern parts of the Mediterranean region.

\section{Representative specimens}

M: Along the seashore road Burg El Arab-Amriya, 27.5.1958; Boulos s.n. (CAI)Near Sidi Besher, Alexandria, 9.10.1923; Simpson 2190 (CAIM)- Gheit El Nassara, Damietta, 11.4.1922; Simpson 983 (CAIM).

5. Plantago crypsoides Boiss., Fl. Orient. 4:888 (1879). (Fig. 1.b)

Type: In arenosis Egypti circa Alexandria. 
Plantaginaceae in the flora of Egypt. 1. Systematic revision of the indigenous taxa

\section{Distribution}

In Egypt, coastal plains along the Mediterranean including barely fields and orchards, southwards in the northern parts of the Libyan and Isthmic Deserts. Known from Libya.

\section{Representative specimens}

M: Sallum, $5 \mathrm{~km}$ E of the frontier, 24.5.1963; Tackholm \& al. s.n. (CAI)- Vicinity of Mersah Matruh, 1.4.1972; Tackholm \& al. s.n. (CAI)- Fuka, 10.4.1932; Shabetai 1717 (CAIM)- King Mariut, 22.1.1928; G. Tackholm s.n. (CAI). Dl: Cairo- Alexandria desert road, 16.4.1961; Tackholm \& al. s.n.(CAI). Di: Wadi Ain El-Gedeirat, 6.4.1939; Drar s.n. (CAIM).

Section: Bauphula Decne, in DC., Prodr.13,1:719(1852).

Annuals, stem \pm elongated, leaves amplexicaulis; seeds large, cymbiform.

6. Plantago amplexicaulis Cav., Icon.Descr. 2:22 (1793)

6.a. P. amplexicaulis subsp. bauphula (Edgew) Rech.fil.,Fl.Iran. 15:11(1965).

= P. bauphula Edgew., In Hook. Journ. Bot. 2:285 (1840).

Type: Malwa et Pentepotamia, Sikh State; Edgew.

\section{Distribution}

Sand plains and wadi beds of the Eastern Desert and Gebel Elba district of Egypt. Known from Palestine, northern parts of Arabian peninsula and eastwards in SW Asia.

\section{Representative specimens}

Di: Wadi El- Gedierat, 15.3.1930; Drar s.n. (CAIM)- El-Kuntilla, 14.5.(1939); Drar s.n. (CAIM). Dg: The area behined Abboud factories, 7.3.1954; El Hadidi s.n. (CAI)Wadi Aber near Suez, 15.2.1966; El Hadidi s.n. (CAI). Da: Wadi Halos, 6.2.1961; Tackholm \& al. s.n. (CAI). R: Hurghada, 5.1933; Muluk s.n. (CAI)- Gebel Samouki, 6.2.1961; Tackholm \& al. 232 (CAI)- Gebel Hamata, 7.2.1961; Tackholm \& al. 325 (CAI). Ge: Gebel Elba, wadi Mera Kwan, 10.2.1962; Tackholm \& al. s.n. (CAI)Gebel Elba, Khor wadi El Shallal, 24.1.1962; Tackholm \& al. s.n. (CAI).

Section: Lagopus Gord. In Gren. \& Godr., Fl. Fr. 2:726(1852-53).

Annual or perennial herbs, stemless, leaves lanceolate, attenuate; seeds concave on ventral side.

7. Plantago lanceolata L., Sp.Pl. ed.1:113 (1753). (Fig. 3.b.)

Type: In Europae campis sterilibus. 


\section{Distribution}

Weed in moist places and the deserts outskirting the arable land of Egypt. Known from central and S Europe, N Africa, SW Asia and Australia.

\section{Representative specimens}

Di: Ismailia, from a garden, 23.6.1936; Shabetai 4858 (CAIM)- Cairo-Inshas road to the left of the road, 15.4.1960; Tackholm s.n. (CAI).

\section{Plantago lagopus L., Sp.Pl.ed.1:114 (1753). (Fig. 3.a.)}

Type: In Gallia Narbonesi, Hispania-Lusitania (LINN, syntype).

$=P$. lusitanica L., Sp.Pl.ed.2:1667 (1763)

\section{Distribution:}

Weed in moist places along the Mediterranean coastal land, cultivations of the Nile land and the Oases of Egypt. Known from S Europe, N Africa, SW Asia and eastwards to Pakistan.

\section{Representative specimens}

M: King Mariut, 22.1.1928; G.Tackholm s.n. (CAI)- Janaklis farm, Abu El-Matamir, 28.5.1967; Tackholm \& al. s.n. (CAI)- Cairo - Alex. Desert road, between Rest House and Amriya, 2.4.1971; Ibrahim \& Mahdi s.n. (CAI)- Rafah, near the station, 22.3.1928; G. Tackholm s.n. (CAI). Nv: Fayium, 3.5.1976;Chrtek s.n. (CAI)- Fayium, 18.4.1952; El Hadidi s.n. (CAI)- Ibshawai, Fayium, 26.3.1923; Simpson 2129 (CAIM). O: Baweti, Bahariya Oasis, 28.3.1934; Drar s.n. (CAI)- Farafra Oasis, Farafra town, 21.3.1968; G. Romee 632 (CAI)- Budkhlu, Dakhla Oasis, 1\& 12.2.1968; G. Romee 155 (CAI)- Ezbet Shiekh Wali, 10.2.1931; Hassib s.n. (CAI)-S of Hibis Temple, Kharga Oasis, 9.1.1939; Runekwitz s.n. (CAI).

Section: Leucopsyllium Decne, in DC. Prodr. 13,1:704 (1852).

Stem short, leaves narrow, often villose; seed thick, longitudinally grooved on ventral side.

9. Plantago albicans L., Sp.Pl.ed.1:114 (1753).

Type: Ex Hispania et Narbona.

\section{Distribution}

Confined mainly to the moist places, barely fields and orchards of the Mediterranean coastal land of Egypt; also in sand plains and wadi beds of Galala desert. Known from S Europe, N Africa, SW Asia; eastwards to Iran.

\section{Representative specimens}

M: Sallum, barely fields, $95 \mathrm{~km}$ E of Sallum, 26.5.1963; Tackholm \& al. s.n. (CAI)Wadi Habis, between Mersa Matruh and Agiba, 23.3.1974; Tackholm \& al. s.n. (CAI)- Burg El Arab, 3 1953; Imam \& Ayaad s.n. (CAIM)- El Arish, 16,3,1928; Drar s.n. (CAIM)- Rafah, near the station, 22.3.1928; G.Tackholm s.n. (CAI). DI: CairoAlexandria desert road, Tahrir province, s of Amria, 5.5.1968; Tackholm \& al. s.n. 
(CAI). Dg:Wadi, El Maadi, 10.10.1972; Saad \& al. s.n. (CAIM)- Suez road K 24 from Heliopolis, 17.4.1953; Fadeel s.n. (CAI).

10. Plantago cylindrica Forssk., Fl.Aegypt.-Arab.:31(1775). (Fig. 3.e.)

Type: Cairo; Forsskal 257, microfiche (C, holotype).

\section{Distribution}

Confined to the $\mathrm{N}$ Mediterranean coastal plains and wadi beds and sand plains of the northern deserts of Egypt. Known from Palestine, Saudi Arabia, eastwards to Iran.

\section{Representative specimens}

M: The way between Berg El Arab and El Alamin, 1.6.1964; Tackholm \& al. s.n. (CAI)- Bir Lehfen S El Arish, 21.3.1928; G.Tackholm s.n. (CAI). Di: Mitla Pass, 10.5.1939; Drar s.n. (CAIM). Dg: Wadi Angabia, 3.1953; El Hadidi s.n. (CAI)- Wadi Lablab, 6.3.1953; Boulos s.n. (CAI)- Wadi Digla of Maadi, 27.1.1966; El Hadidi \& Boulos s.n. (CAI).

11. Plantago ovata Forssk., Fl. Aegypt.-Arab.:31 (1775)

Type: Alexandria, Forsskal 253, microfiche (C, holotype).

$=P$. decumbens Forssk., Fl.Aegypt.-Arab.:30 (1775).

\section{Distribution}

In Egypt, coastal plains along the Mediterranean and Red Sea, sand plains and wadi beds of the deserts of Sinai specially after rain. Known from NW America, Atlantic Islands, Mediterranean regions, and SW Asia, eastwards to Pakistan.

\section{Representative specimens}

M: El Alamin, $110 \mathrm{~km} \mathrm{~W}$ of Alexandria, 27.22.1968; G.Romee s.n. (CAI)- El Arish, 20.3.1928; G. Tackholm s.n. (CAI). Di: A branch of El Maghara, 22.4.1959; Boulos s.n. (CAI \& CAIM)- Wadi El Gedierat, 19.3.1930; Drar s.n. (CAIM)- Nekhl, 10.5.1959; Drar s.n. (CAIM)- In the desert N of wadi Timulat on Bilbeis-Ismailia road, 15.4.1960; Tackholm s.n.(CAI). Dl: Abu Rawash road, Giza, 22.3.1957; Soad s.n. (CAI). Dg: Wadi Aber, G. Ataqa, Suez, 15.2.1956; Tackholm s.n. (CAI)-Wadi El Ghomeyla, 16.3.1937; Shabetai 3611 (CAI \& CAIM)- Wadi Lablab, near G. Ahmer, Cairo, 17.3.1957; Imam \& Ayyad s.n. (CAI). S: Wadi Ramliya, W of wadi ElArbaain, 12.4.1945; Shabetai 5656; (CAIM). R: Road between Ain Sukhuna and Bir Udeib, 13.3.1954; Boulos s.n. (CAI).

12. Plantago ciliata Desf., Fl. Atlant.1:137, tab.39, fig.3 (1798).(Fig. 3.e.)

Type: In arenis deserti prope Cassam et Elhammah.

\section{Distribution}

In Egypt, sand plains and wadi beds western of the Eastern Desert, Gebel Elba district and the Oases. Known from Canary Island N Africa, SW Asia and Arabia peninsula. 


\section{Representative specimens}

M: El Amriya, Maruit, 10.4.1971; Imam \& Mahdi s.n. (CAI). Di: Tel El Kebir, 5.8.1931; Drar s.n. (CAIM). Dl: Tahrir Pronince, 8.6.1973; Ibrahim \& al. s.n. (CAI). Da: Wadi Gemal, 6.2.1961; Tackholm \& al. s.n. (CAI)- 179 km E of Edfu, 10.2.1961; Tackholm \& al. s.n. (CAI). O: El Agguz, Bahariya Oasis, 17.4.1935; Drar s.n. (CAIM)- Kharga Oasis, 2.10.1928; Drar s.n. (CAIM). R: Between El Shatt and Abu Zeneima, 14.4.1937; Shabetai (CAIM)- Gebel El Faraied, 6.2.1961; Tackholm \& al. s.n. (CAI).

13. Plantago notata Lag., Gen.Sp.Pl.:7 (1816).(Fig. 3.d.)

Type: Hispania, Pulpi inter Cuevas et Heliocrata.

\section{Distribution}

In Egypt, Mediterranean coastal plains and southwards in sandy deserts. Known from Spain, N Africa, SW Asia, Iraq and Iran.

\section{Representative specimens}

M: Wadi Umm El Rakham, between Mersa Matruh and Agiba, 23.3.1974; Tackholm \& al. s.n. (CAI)- Dabaa, 3.5.1955; Tackholm \& al. s.n. (CAI)- Along the road Amriya-Burg El Arab, 24.3.1961; Tackholm \& al. s.n. (CAI). DI: Cairo-Alexandria desert road, $180 \mathrm{~km}$ from Cairo, in field W of the road, 16.4.1967; Tackholm \& al. s.n. (CAI).

II. Subgenus: Psyllium (Juss.) Harms in Engler \& Prantl, Pflanzenfam. 4,310:373(1895).

Annual, small shrubs, with more or less elongated, branched stems, leaves opposite, narrow.

Section: Psyllium (Juss.)DC. In Lam. \& DC., Fl.Fr.ed.3,3:409(1805).

Plant glandulose; spike short, anterior sepals slightly concave, posterior sepals broadly concave, corolla tube glabrous, rugulose.

14. Plantago sinaica (Barneoud) Decne, In DC. Prodr.13,1:733 (1852).

Type: not indicated.

$=P$. psyllium L. var. sinaica Barneoud, Monogr.Plantag.:49(1845).

$=$ P. arabica Boiss., Diagn. Fl. Orient. 12:94(1853), nom. illeg.

\section{Distribution}

In Egypt, confined to rocky habitats of southern Sinai. Endemic to mountainous Sinai.

\section{Representative specimens}

S: Gebel El Deir, near St Catherine Monastery, 10.5.1956; El Hadidi s.n. (CAI)Geneinet El Arbaain, foot of Mt.St.Catherine, 16.4.1937; Shabetai s.n. (CAIM)- 
Abu Himan, 2.4.1927; Kaiser s.n. (CAI)- On the top of Gebel Musa, 22.4.1967; Tackholm \& al. s.n. (CAI).

15. Plantago phaeostoma Boiss. \& Heldr., in Boiss. Diagn.Pl.Orient. ser.2,4:71(1859).

Type: In Aegypto prope Alexandria; Samaritani.

\section{Distribution}

In Egypt, coastal plains along the Mediterranean Sea and wadi beds in northern desert. Known from Libya and Arabian peninsula.

\section{Representative specimens}

M: Burg El Arab, 28.3.1957; Tackholm s.n. (CAI). Di: Wadi El Gedeirat, 4.4.1939; Drar s.n. (CAI).

16. Plantago squarrosa Murray, Comment. Soc.Regiae Sci. Gott.4:38 (1782).

(Fig. 2.c.)

Type: not indicated.

$=$ P. aegyptiaca Jacq., Coll. 1:45 (1786)

\section{Distribution:}

In Egypt, the Mediterranean coastal plains, dry and sandy places. Known from Crete, Greece and Libya.

\section{Representative Specimens}

M: Saniet El Hagg Ayyd, wadi Habs, between Mersa Matruh and Agiba, 22.3.1974; Tackholm \& al. s.n. (CAI)- Maamourah, NE Alexandria, 22.3.1911; Hartmann s.n. (CAI)- Abu Mandor- Rosetta, 11.3.1978; Soliman s.n. (CAI)- Al Arish, 20.3.1928; G. Tackholm s.n. (CAI).

17. Plantago arenaria Waldst.\& Kit., Pl. Rar.Hung.1: 51.tab.51(1802). (Fig.1.c \&2.a.)

Type: Described from Hungary.

$=P$. psyllium L., Sp.Pl. ed.1:115 (1753). nom. confus

$=P$. indica L., Syst. Nat.ed.10:896 (1759). nom. illeg.

$=P$. ramosa (Gilib.) Aschers., Fl. Brandenb. 1:547 (1864). nom. illeg.

\section{Distribution}

Weed of recent introduction to the Oases of the Western Desert,Egypt. Known from Temperate Europe, N Africa, SW Asia, eastwards to Pakistan.

\section{Representative specimens}

O: Bahariya Oasis, El Heiz, Ain Tablamon, 15.5.1978; Abdel-Ghani s.n. (CAI)Dakhla Oasis, Rashda, 6.2.1929; Drar s.n. (CAI)- Kharga Oasis, in agris., 12.3.1967; El Hadidi \& al. s.n. (CAI). 
18. Plantago exigua Murray, Comment. Soc. Regiae Sci. Gott. 1:94 (1779). (Fig. 2.d.)

Type: ex Aegypto, Verosimiliter.

$=P$. pumila L. fil., Suppl. Pl.:125 (1782).

\section{Distribution}

In Egypt, weed in fields and orchards of the Oases as an escape from cultivation. Known from Iran, Afghanistan and Pakistan.

\section{Representative specimens}

O: wadi El Natrun, 3.1970; Naguib s.n. (CAI)- Bahariya Oasis, El Gedida village, weed in gardens, 20.1.1979; Abdel-Ghani s.n. (CAI)- Kharga Oasis, in agris prop. Kharga, 12.3.1967; El Hadidi \& al. s.n. (CAI).

19. Plantago afra L. Sp.Pl. ed.2:167 (1762). (Fig. 2.b.)

$=P$. psyllium sensu L., Sp.Pl. ed.2:167 (1762). nom. ambig.

$=P$. parviflora Desf., Fl. Atlant. 1:141 (1798).

Type: Habitat in regno Tunetano.

\section{Distribution}

In Egypt, coastal plains along the Mediterranean and Red Sea coastal lands, Sinai and Elba District. Known from N Africa, eastwards to SW Asia.

\section{Representative specimens}

M: Bir-Lehfen, El Arish, 21.3.1928; G.Tackholm s.n. (CAI). Di: Tel El Kebir, 9.2.1939; Shabetai 7609 (CAIM). Dl: Wadi Natroun, 11.5.1970; Imam s.n. (CAI). Dg: Wadi Nooz, N Galala, 2.4.1929; Simpson 2853 (CAIM). O: El Kharga Oasis, 19.3.1962; Sharobim \& Shalaby 1678 (CAIM). S: Ain Shenarah, 18.4.1927; Kaiser 1270 ((CAIM). R: Wadi El Hankaila, near the gold mines, 4.2.1961; Tackholm \& al. 338 (CAI).Ge: Wadi Mawaw, 28.1.1962; Tackholm \& al. 885 \& 950 (CAI)- Wadi Kansisrob, 24.1.1933; Shabetai 2700 (CAIM).

\section{References}

Bessey, C.E. 1915. The Phylogenetic Taxonomy of Flowering Plants-Ann. Mo. Bot. Gard. 2:109-164.

Boulos, L. 1995. Flora of Egypt, Checklist: 141-143. Cairo, El Hadara Press. Chater, A.O. \& Cartier, D. 1976. Plantaginaceae, in T.G. Tutin (ed.), Flora Europaea 4:38-44. Cambridge University Press.

El Hadidi, M.N. 1993. Natural vegetation in G. M. craig (ed.). The Agriculture of Egypt:39-62. Oxford University press.

\& Fayed, A.A. 1994/95. Materials for Excursion Flora of Egypt. Taeckholmia 15: 512-514.

Feinbrun, N.D. 1978. Flora Palastina 3:220-229. Jerusalem Academic Press.

Hallier, H. 1912. L'origine et la systeme phyletique des angiospermes exposes a l'aide de leure arbre genealogique. Arch.Neere Sci. exact et Nat. ser.III.13.

Hutchinson, J. 1948. British Flowering Plants : 374. London. 
Plantaginaceae in the flora of Egypt. 1. Systematic revision of the indigenous taxa

Moore, D.M. 1978. Plantaginaceae , in V.H. Heywood (ed.), Flowering Plants of the World : 241-252. Oxford University Press. London.

Pilger, R. 1937. Plantaginaceae, in A. Engler, Planzenreich 4,269:1-466. Berlin.

Tackholm, V. 1974. Student 's Flora of Egypt ed.2:515-516. Cairo University.

Wettstein, R. 1935. Hanbuch der Systematischen Botanik ed.4:1152. Leipzig and Wien. 